\title{
Study on College English Teaching from the Perspective of Communication
}

\author{
Ling-Ling ZUO \\ Ningbo Dahongying University \\ Ningbo, China \\ 514949943@qq.com
}

\begin{abstract}
College English teaching is an important part of English education, which is the critical stage to learn English and then apply the knowledge and skills to the real life. English classroom teaching is the transmission of information or the operation of information systems. It is a complete process of communication. Based on previous studies, this paper studies the teacher's discourse strategies through the methods of questionnaire and personal interview. This paper uses the theory of communication to explore the mode of communication of college English teaching, analyzes the factors of communication in college English teaching and puts forward the effective strategies of improving college English teaching. The innovation is to study the discourse strategies of college English teachers in application-oriented colleges from the perspective of communication, and combine the theory with the actual situation of students, so as to instruct teachers to better use discourse strategies to organize classroom teaching.
\end{abstract}

Keywords-communication; college English teaching; teaching patterns; discourse strategies

\section{INTRODUCTION}

Communication is a subject studying on all human communication and dissemination in the process of occurrence and development of the law and the spread of the relationship between man and society. It is also the science studying on social information systems and the laws of its operation. In short, communication is a science studying on how humans use symbols for social information exchange.

From the etymological point of view, it is derived from the Latin "communicate", meaning "so common." Thus, communication is shared from the professional point of view, communication is the transmission of social information or the operation of social information system, and it is a kind of social information system, which is a kind of social information system. In the modern society, people talk, read and read newspapers and surf the Internet and other activities involve information sharing, including communicators, recipients, messages, the media and feedback.

College English teaching also involves the transmission of information or the operation of information systems. In the process of teaching, the teacher sends out the information in the English language. The teacher is the collector, the processor and the transmitter of the information. In the process of learning, the students receive the information from the teacher and appraise and feedback the communication effect. They are the direct participants of the communication activities.

Information is the core of teachers and students to point to, that is, English language knowledge, which is able to express the full meaning of the information; Communication media is the dissemination or load of information material entities, such as textbooks, electronic courseware, teachers; the response to the message originator is the reverse flow of information. Thus, English classroom teaching is a complete process of communication.

\section{Present Situation of College English Class in PRIVATE COLLEGES}

As a result of the traditional concept and the private institution itself started late, small scale and other reasons, private colleges and universities in enrollment has been at a disadvantage, according to three admission students. Student foundation is relatively poor, learning consciousness is not very high. They need to be strictly supervised by the teachers. Therefore, the college English teaching in private colleges and universities must adopt effective classroom strategies to improve students' English proficiency so that they can reach or approach the English proficiency of one or two students and become practical talents in society.

English learning in Private universities has its outstanding features, mainly including: students' basic knowledge is not solid, level of uneven, poor self-learning ability, inner vulnerability and so on. Obviously, the focus of colleges and universities that the teaching model is not suitable for private college English teaching. However, many college English teachers in private colleges and universities have been using this "professorship" classroom teaching mode. Teachers sing a one-man show, students in the class to sleep, or even skip classes. This time-consuming, inefficient situation so that teachers feel lost, at a loss, no sense of accomplishment. This English class is inefficient, or even ineffective. Under the condition of not changing the objective factors such as poor foundation, we can change how to construct the English classroom of private colleges.[5] 


\section{College ENGlish TeACHers ARE THE SubJeCt OF ENGLISH CLASSROOM TEACHING}

A. College teachers are gatekeepers in the process of selecting pre-class information.

During the entire college English teaching communication activities, teachers determine the contents of information dissemination activities. In the pre-class, college teachers start from their own academic background, filter and choose the information which they need teach. Teachers launch communication activities; become the subjects of teaching communication activities.

B. College teachers should make use of communication skills; disseminate the selected information effectively to college students.

They are the organizers of the communication activities. This link is the center of teaching. University teachers, the selected information and university students constitute a complete communication activity. As the dominant communicators, university teachers are the core of these three elements of communication, organizing the entire communication activities. Their dominant position is fully reflected.[4]

\section{After the spread of activities is completed, the dissemination of the results will be the first time feedback, college teachers are the direct practitioner.}

Spreading effect is the transmission of information by the communicator to reach the audience through a certain media channels, so that the audience's thoughts, attitudes, actions, etc. have different degrees of change. [6]Communication effect analysis, the whole process of communication test, you can test the content of the appropriate communication, the media is feasible, the communicator and the audience is normal and so on whether the communication activities to achieve the desired goal of an important link. In this session, after the course is taught, the college teachers can effectively evaluate the effect of communication activities by observing the students' attitudes towards the information and the changes of their learning behaviors, using on-site questionnaires and after-school questionnaires.

\section{ANALysis ON THE SPREAdING PATTERNS OF COLLEGE ENGLISH TEACHING}

Education is the combination of "teaching" and "learning". Teachers pass knowledge to students, students successfully accept knowledge, education is successful, and the dissemination of knowledge is successful. Thus, classroom communication is a two-way process.[9]

The traditional college English teaching emphasizes "teaching", while ignoring the "learning", so the classroom communication is unsuccessful. This linear one-way transmission is known as the "Shannon-Weaver" communication model, which is put forward by the information theory founder, mathematician Claude Shannon and his colleagues Voivet in 1949. This model was first used to explain the process of telegraph communication mode of communication, the scope of application has been gradually expanded, including for education and teaching research. The advantage of this model is that it contains the "noise" factor. In college English teaching, it refers to the interference factors that affect students to accept knowledge, such as the emergence of new words, the unfamiliar social and cultural backgrounds and the improper use of multimedia.

The ideal college English teaching should be studentcentered, the students receive the information of teachers, and they will feedback the teaching effect and teaching evaluation to the teachers. Teachers and students are participants in classroom teaching, both to send information, but also to accept information. This two-way communication is in line with mass communication theory which was put forward by the American communication founder Wilbur Schramm. He believes that the recipients are a part of certain social groups. When they receive and disseminate the information, they will be affected by other members of the group. Information dissemination is the process of two-way cycle; each member is both a communicator and a recipient.

\section{StRAtegies to IMPROVE THE EFFECTIVENESS OF COLLEGE ENGLISH TEACHING}

\section{A. Teacher 's Discourse Strategy.}

According to Krashen's comprehensible input, the teacher's discourse in the English classroom should be a comprehensible language, which is the $\mathrm{i}+1$ pattern. [1]That is, the teacher's comprehensible language input should be slightly higher than the student's language level. This is the most conducive to students to learn or acquire the language. Therefore college English teachers should provide students with the most authentic input of target language. And strive to build English teachers and students to participate in the classroom. Teachers should reduce the amount of classroom discourse, increase the amount of students' discourse, provide students with more opportunities for language output, and promote classroom communication. At the same time, teachers should improve the quality of discourse. The classroom role of college English teachers should be transformed into classroom leaders and classroom information providers.

\section{B. Use the Appropriate Questioning Strategy.}

College English teachers should first increase the number of reference questions, that is, the number of non-limited questions. Triggering students more words. Promote more students to start turn-taking. Second. Teachers should extend the question waiting time. Increase the number of sessions between students. If we believe that when learners are pushed to the limits of their language ability to maximize the promotion of language acquisition then the teacher's waiting time should be increased. Finally, the teacher should assign the problems to all students. Rather than just selecting individual students to answer. When all the students have the same opportunity to answer questions, all students will pay attention to the problem and actively participate in classroom activities. 


\section{Let the Turn Round Strategy.}

Generally speaking, each speaker speaks from the beginning to stop talking for a turn. The turn allocation in the session indicates the allocation of the floor. The distribution of the right to speak and the length of the speech depend on the speaker and the listener in turn-turn rules under the constraints of competition and coordination. The resulting turn round distribution reflects the relationship between the conversations. Steviek advocates classroom discourse of the turn should be teacher control. [2]The student-initiated model is teachercontrol and student-initiate. In other words, teachers control the turn. But does not interfere with the student-initiated turntaking. When the teachers to strengthen the control of the classroom turn when there is no need to intervene in the student initiated the turn. Teachers should use the turn-taking strategy to give the right to control, so that teachers and students turn one after another, constantly changing. Classroom interaction can not only promote the progress of teaching. It is for the learners to create language output opportunities, thereby promoting their English learning.

\section{Appropriate Use of the Meaning of Consultation and Discourse Recovery Strategies.}

In the classroom, in order to promote interaction between teachers and students and the significance of consultation, it should be used to confirm the verification strategy and request clarification strategy. In particular, it requires a clarification strategy, which can lead to more learners' turn-taking and provide opportunities for learners to use target language. Improve their language output ability and communicative ability. Simultaneously teachers can also repeat their own problems, or give students a certain amount of time, so that learners participate in classroom activities by thinking. To promote the "push" language output, for students to create language output opportunities and time, thus promoting classroom interaction and learner language acquisition.[8] In order to make the exchange between teachers and students in the classroom smooth. At the same time in order to promote the classroom between teachers and students to carry out the smooth progress of the topic. Teachers should make use of negotiation of meaning and conversational modification.

\section{E. Feedback Mode Strategy.}

In College English Classroom Teaching, college English teachers should give students positive feedback (praise or comment), so that students have the opportunities to correct their own mistakes. Students should be given sufficient time to answer questions, encourage them to correct their mistakes in a timely manner, or teachers may also give some hints. Again, in the use of error correction strategy to restate, to avoid overcorrecting errors to the learner in a state of tension. [7]Simultaneously. Negative feedback also causes students to become more passive in the classroom, not the courage to answer questions, learning interest decline. And positive feedback can increase students' self-confidence, improve their interest in learning and stimulate their enthusiasm to participate in classroom interaction, which undoubtedly play a very important role in English acquisition. The language output of any learner is also the input of the whole class. If the teacher does not correct the errors in the learner's language, the learner may think the expression is correct. And internalize the wrong language. However, if the teacher to give a clear corrective and may lead to the loss of students face the problem, so restatement strategy is to solve the contradiction between the two better strategy.

\section{F. Appropriate use of mother tongue strategies.}

According to Krashen's input hypothesis, the input of the language requires not only quantity. It also requires the input language to be understandable. Krashen's comprehensible input is based on the "success of communication" basis. The success of this communication should be the success of the use of target language communication. Rather than our teachers us their mother tongues to communicate. Because we communicate in the foreign language classroom is the purpose of learning this foreign language. As the target language and the mother tongue there are many unequal or asymmetric phenomenon. The difference between the different languages may lead to misunderstanding of language learners. This will greatly affect the efficiency and motivation of learners. At this time the use of native language to explain the target language can help students understand the meaning of the original word so as to improve learners' understanding of target language. As a result, teachers use their mother tongue in explaining complicated and difficult language points, and the mother tongue plays a role as a lubricant. Will help students to understand and better acquire language.[3]

\section{CONCLUSION}

In the field of communication, the college English teaching is regarded as the complete communication activity constructed by the college teachers in the pre-class information filtering, information dissemination on the podium and assessment of the teaching effect. As the initiators and organizers of the communication activities, the decision makers of the choice of information and communication methods, and the first receivers of communication effect feedback, the university teachers should, on the basis of full recognition of the characteristics of college students' audience, The gatekeeper, pay attention to the application of communication skills, to break the pattern of one-way transfer relationship to strengthen the dissemination of results analysis, to achieve teaching objectives. In the practice of teaching, the harmony between the subject and the object is enhanced, and the communicative ability of the communicator (the teacher) and the acceptability of the information of the audience (college students) are enhanced through multi-channel and multi-carrier communication. In the communication activities, pay more attention to the effect of communication and teaching communication activities, will promote the development of college English education and expected to achieve the effect of education

Under the view of communication, college English teaching is a complete communication activity constructed by teachers, communication information and college students. Observing the English teaching of college students with the classical communication theory can broaden the teaching 
horizons, enrich the teaching methods, enhance the pertinence and effect of teaching, and improve the English teaching.

College English teaching is one of the main ways for students to learn English in college. Teachers' classroom teaching is not only a tool for teachers to perform teaching tasks, but also a major way for students to input English language. In the College English classroom, teachers should use a variety of effective strategies to mobilize the enthusiasm of students to learn, to give students sufficient time to enter the language, to maintain a good classroom atmosphere and harmonious teacher-student relationship.

In the communication activities of college English teaching, teachers should combine the characteristics of college English teaching, aiming at the thinking, ability and habits of college students, with the help of communication theory, to better convey the information to the students to further improve the teaching level.

\section{REFERENCES}

[1] Ellis,Rod. Understanding Second Language Acquisition[M]. Shanghai Foreign Language Education Press, 1985.

[2] Krasherl,S. D. The Input Hypothesi[M],New York:Longumn,1985.

[3] Swain,MJnput in Second Language Acquisition [M].Rowley,Mass:Newbury House,1985.

[4] ZHAO Xin.Analysis of college students' teaching of public English and modern market economy [J]. Success (Education), 2007 (7).

[5] Shao Peiren. Communication [M]. Beijing: Higher Education Press, 2000.46.

[6] Guo Qingguang. Communication Studies [M]. Beijing: Renmin University of China Press, 1999.203.

[7] LONG Jian-mei,.Discussion on classroom communication research [J] .Journal of Hunan City University, 2012 (04): 105-108.

[8] MAO Hui,.Noise and Noise Reduction Strategies in College English Speech Teaching from the Perspective of Communication Theory [J] .Science \& Technology, 2013

[9] Kang Jian. Communication from the perspective of college English audio-visual teaching analysis [j]. Taiyuan Teachers College (Social Sciences), 2011 